\title{
Esterases and Other Soluble Proteins of Some Lactic Acid Bacteria
}

\author{
By T. MORICHI,* M. ELISABETH SHARPE AND \\ B. REITER \\ National Institute for Research in Dairying, Shinfield, Reading
}

(Accepted for publication 8 May 1968)

\begin{abstract}
SUMMARY
Electrophoresis patterns of soluble protein of 34 strains and esterases of I 3 strains of lactic acid bacteria were determined. Similar protein patterns were obtained for the three species of lactic acid streptococci; with the lactobacilli most species gave constant species-specific patterns, but Lactobacillus acidophilus and $L$. delbrueckii strains differed markedly among themselves. Esterase patterns of lactic streptococci were generally species specific. Among the lactobacilli the thermobacteria had weak esterase activity which was only species specific for $L$. lactis, $L$. leichmanii and $L$. salivarius; in the streptobacteria, $L$. case $i$ had a very consistent esterase pattern, whereas $L$. plantarum had very different patterns within the species; the unclassified strains were different from each other; in the betabacteria activity was weak and no consistent pattern of bands occurred. Leuconostocs grouped in patterns corresponding to their physiological groups. Esterases of a streptococcus and a lactobacillus examined were classified as ali esterases. When ten strains of lactic acid bacteria were tested for substrate specificity, nine of them had a higher activity against $\alpha$-naphthyl acetate than against the butyrate and caprylate. A rapid test for esterase activity of whole organisms is described.
\end{abstract}

\section{INTRODUCTION}

Lactic acid bacteria have been differentiated by physiological and serological tests into several well-defined groups or species, but a further understanding of their relationships might result if the electrophoretic patterns of their esterases and other soluble proteins were compared, as has already been shown for other groups of bacteria (Norris, 1964; Cann \& Willox, 1965; Lund, 1965; Robinson, 1966). These lactic acid bacteria occur in large numbers in Cheddar cheese and the presence of esterases in different strains of these organisms might effect the breakdown of ester linkages of substances present in the cheese, and produce compounds contributing to the cheese flavour (Reiter, Fryer, Sharpe \& Lawrence, 1966; Reiter et al. 1967). The relative activity of the different esterases might determine the quality of flavour. In experiments reported here, the multiple esterases of group $\mathrm{N}$ streptococci, lactobacilli and leuconostocs were studied, and the soluble protein electrophoretic patterns of some of the group $\mathrm{N}$ streptococci and the lactobacilli determined.

\footnotetext{
* Present address: National Institute of Animal Industry, Chiba-Shi, Japan.
} 


\section{METHODS}

Organisms. The following II 3 strains of lactic acid bacteria were used: Streptococcus cremoris HP, OP4, TEM2, RW, YP7, K, FH, HS2, UD5, AMI, TR, D9, RI, MLI, KH, 924, E8, ML2, R6, 803; S. lactis SC2, SC6, SCIO, M2SI, ML3, 7I2; S. diacetilactis DRCI, DRC2; Lactobacillus casei $\mathrm{C2}, \mathrm{C} 4, \mathrm{C} 5, \mathrm{C} 6, \mathrm{C} 7, \mathrm{C} 9, \mathrm{Cl} 2, \mathrm{C} 2 \mathrm{O}, \mathrm{C22}, \mathrm{C} 24, \mathrm{C} 25, \mathrm{C} 42 ;$ L. casei var. rhamnosus $\mathrm{C} 3, \mathrm{CI}, \mathrm{CI} 6, \mathrm{C} 34$; L. casei var. alactosus $\mathrm{C} 3 \mathrm{I}$; L. plantarum $\mathrm{PI}, \mathrm{P} 5, \mathrm{PI} 2$, AR3, AI64; unclassified streptobacteria K44, A4I, AIOI, D45, V4, V5; L. helveticus $\mathrm{H}_{4}$, H5, HI7; L. jugurti J2, J4, J8; L. bulgaricus B4, B8, BI7; L. lactis LI, L3, L19, AH7; L. acidophilus AI, A4, AI5; L. leichmannii LE2, LE3, LE4; L. delbrueckii D2, D6, DIO; L. salivarius SALI, SAL5, SAL9, SALIO, SALI I, SALI $3 ;$ L. fermenti FI, FI5, F38; L. buchneri BCI, BC5, L. brevis XI, X2, X5; L. cellobiosus GI, G2, G3; L. pastorianus TI, T9; Leuconostoc cremoris NCDO 705, 828, 543; Ln. lactis NCDO 534; Ln. dextranicum NCDO 529, Ln. mesenteroides NCDO 803, 869, 870, 87I, 516, 5I8, 523, 530, 55I, 553.

All the test cultures were from a stock collection at the National Institute for Research in Dairying or from the National Collection of Dairy Organisms.

Culture procedures. Lactic streptococci were grown for $18 \mathrm{hr}$ at $30^{\circ}$ in $500 \mathrm{ml}$. MRS broth (de Man, Rogosa \& Sharpe, 1960). With the lactobacilli, thermobacteria and L. fermenti were grown for $18 \mathrm{hr}$ at $37^{\circ}$ in $500 \mathrm{ml}$. MRS broth (de Man, Rogosa \& Sharpe, 1960). The other betabacteria and the streptobacteria were grown for $\mathrm{I} 8 \mathrm{hr}$ at $30^{\circ}$. Leuconostocs were incubated for $18 \mathrm{hr}$ at $30^{\circ}$ in $500 \mathrm{ml}$. MRS broth containing $0.05 \%$ cysteine (Dr E. I. Garvie, personal communication). Incubation periods were for 36 to $40 \mathrm{hr}$ for some slow-growing strains of lactobacilli and leuconostocs (e.g. FI5, XI, BC5, TI, 705).

Preparation of cell-free extracts. The bacteria were harvested by centrifugation, washed three times with chilled physiological saline or $0 \cdot 1$ M-phosphate buffer ( $\mathrm{pH}$ $8 \cdot 0$ ) and suspended in 4 to Io $\mathrm{ml}$. saline. After the addition of Ballotini beads, the bacteria were disintegrated for I 5 to $30 \mathrm{~min}$. by Soniprobe type I I 30 A (Dawe Instruments Ltd.) the containers being immersed in solid $\mathrm{CO}_{2}+$ methanol $\left(-20^{\circ}\right)$. The extracts were clarified by centrifugation and stored at $-20^{\circ}$ until required. The extracts contained Io to $20 \mathrm{mg}$. protein $/ \mathrm{ml}$. estimated by the biuret micro-method (Itzhaki \& Gill, 1964) with crystallized bovine plasma albumin as standard.

Electrophoresis of proteins and esterases. The cell-free extracts were analysed by electrophoresis in polyacrylamide gels. The gel preparation, electrophoresis, protein and esterase staining were done mainly according to the procedures described by Lund (1965). Samples were applied by absorbing 6 to $8 \mu \mathrm{ml}$. of extract on pieces of Whatman $3 \mathrm{MM}$ filter paper and inserting them into the gels. To detect very faint esterase bands as with Lactobacillus casei it was necessary to apply 30 to $50 \mu \mathrm{ml}$. of extract. One \% solution of $\alpha$-naphthyl acetate, -butyrate, -caprylate or -laurate were used as substrates for detecting esterases. The solutions of the caprylate and laurate derivatives contained propylene glycol to give good stability (Gomori, I953). Fast blue $B$ salt was used as coupling dye to indicate hydrolysis.

Esterase stain. Since pH 8.0 is known to be optimal for the activity of some esterases, the optimum reaction of the staining solution was investigated. When the Fast Blue B salt was dissolved together with substrate in a buffer according to the procedure described by Lawrence, Melnick \& Weimer (1960) the best result was obtained at the

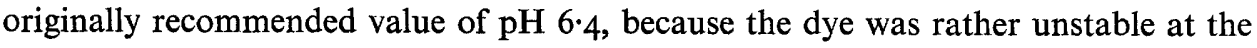


higher $\mathrm{pH}$ value. It was possible and sometimes useful to separate the ester hydrolysis (at $\mathrm{pH} 6.4$ to 8.0 for $\mathrm{I} \mathrm{hr}$ at room temperature) from the following diazo-coupling (at $\mathrm{pH}$ 6.4). The apparent rate of hydrolysis by a majority of the esterases examined was practically the same in the range $\mathrm{pH} 6.4$ to $8 \cdot 0$. Test cultures used were Lactobacillus casei $\mathrm{C} 5, \mathrm{C} 9$, L. plantarum PI, L. helveticus $\mathrm{HI} 7$ and Streptococcus cremoris HP. Accordingly, in the present work, the pH value of the staining solution within the abovementioned range was not so important, because the gel itself contained tris citrate buffer ( $\mathrm{pH} \mathrm{8.65).} \mathrm{When} \mathrm{compared} \mathrm{with} \mathrm{each} \mathrm{other} \mathrm{as} \mathrm{coupling} \mathrm{dye,} \mathrm{Fast} \mathrm{blue} \mathrm{B} \mathrm{salt}$ gave better colour development than Fast blue BB or RR salts.

Comparison between polyacrylamide and starch gels. Lund (1965) pointed out that faint esterase bands seem to be more sensitively detected on starch gel than on polyacrylamide gel. When we compared the esterase patterns on both gels, using cellfree extracts of Lactobacillus casei C9, L. plantarum P5, Streptococcus lactis ML3, $S$. diacetilactis DRCI, $S$. cremoris 924 , and Leuconostoc cremoris 828 , the same or better results were obtained in the polyacrylamide gel. Polyacrylamide gels could not be used for quantitative work because it was almost impossible to extract the developed colour substance from the gel. Quantitative determinations of esterase activities of $L$. case $i$ c9 were therefore made after starch-gel electrophoresis (Wright \& Keck, I96I). The starch-gel slices were flooded separately with the staining solutions containing $\alpha$-naphthyl acetate or butyrate. The reaction bands were eluted with $n$-amyl acetate + ethanol ( $\mathrm{I}+\mathrm{I}$ by vol.) and determined colorimetrically at $500 \mathrm{~m} \mu$. Relative activities for acetate and butyrate esters were as follows: prominent esterase, Ioo and 28; butyrate-specific, minor esterase, 3 and 17 .

Growth media. The influence of different media upon the esterase patterns of lactobacilli were examined by using Lactobacillus casei C2, C9 and L. plantarum PI as test organisms. Media used were as follows: APT (Evans \& Niven, 195I), Rogosa (Efthymiou \& Arne Hansen, 1962), MRS broth, MRS broth with glucose decreased to $0.5 \%$ and MRS broth with Bacto peptone instead of Oxoid peptone. No significant differences were detected. Nor was any qualitative difference noted between the esterase patterns of lactic streptococci grown in glucose I \% Lemco broth (GLB) or in GLB $+0.2 \%$ yeast extract (Oxoid). The same pattern was obtained with Leuconostoc mesenteroides 869 harvested from MRSB $+0.05 \%$ cysteine or from YG citrate broth (Garvie, I960).

\section{RESULTS}

\section{Soluble protein electrophoretic patterns of lactic acid bacteria}

Streptococci. The variations in the patterns of soluble protein between the three species of lactic streptococci were small. Representative patterns of Streptococcus cremoris, $S$. lactis and $S$. diacetilactis were very similar, although a few protein bands in the $S$. lactis pattern were not detected in that of $S$. cremoris.

Lactobacilli. Most of the species gave consistent characteristic patterns which were different for each species. Lactobacillus helveticus and L. jugurti, which are closely related to each other, showed similar but not identical patterns and so did L. lactis and $L$. bulgaricus, two other closely related species. Six strains of $L$. casei showed identical patterns apart from two very weak bands; there was no difference between patterns of strains belonging to serological groups B and C.

L. plantarum strains showed a similar overall pattern with a few weak bands dif- 
ferent. However, the protein patterns of $L$. acidophilus and $L$. delbrueckii, particularly the latter, showed considerable variation between strains: among the heterofermentative strains examined $L$. cellobiosus differed markedly from $L$. buchneri.

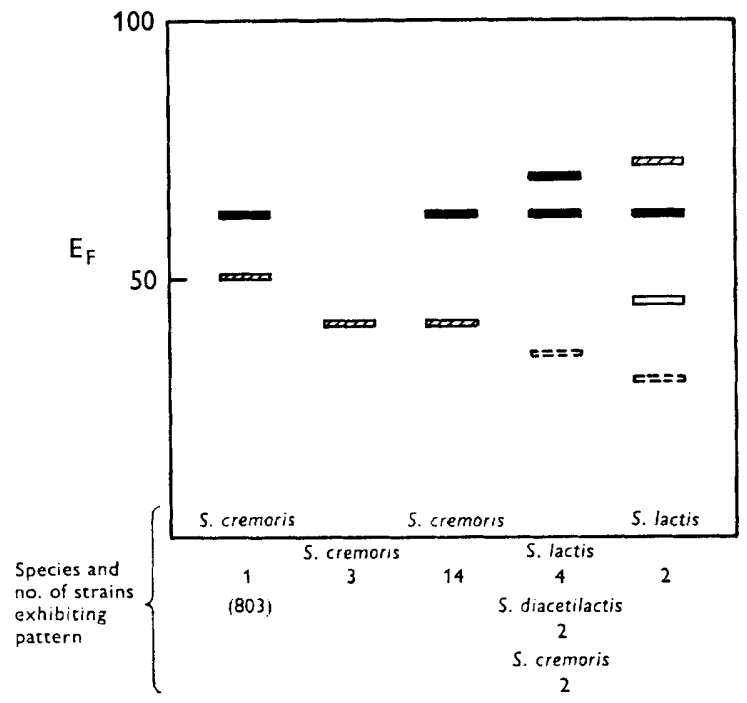

Fig. I. Esterase patterns of lactic streptococci.

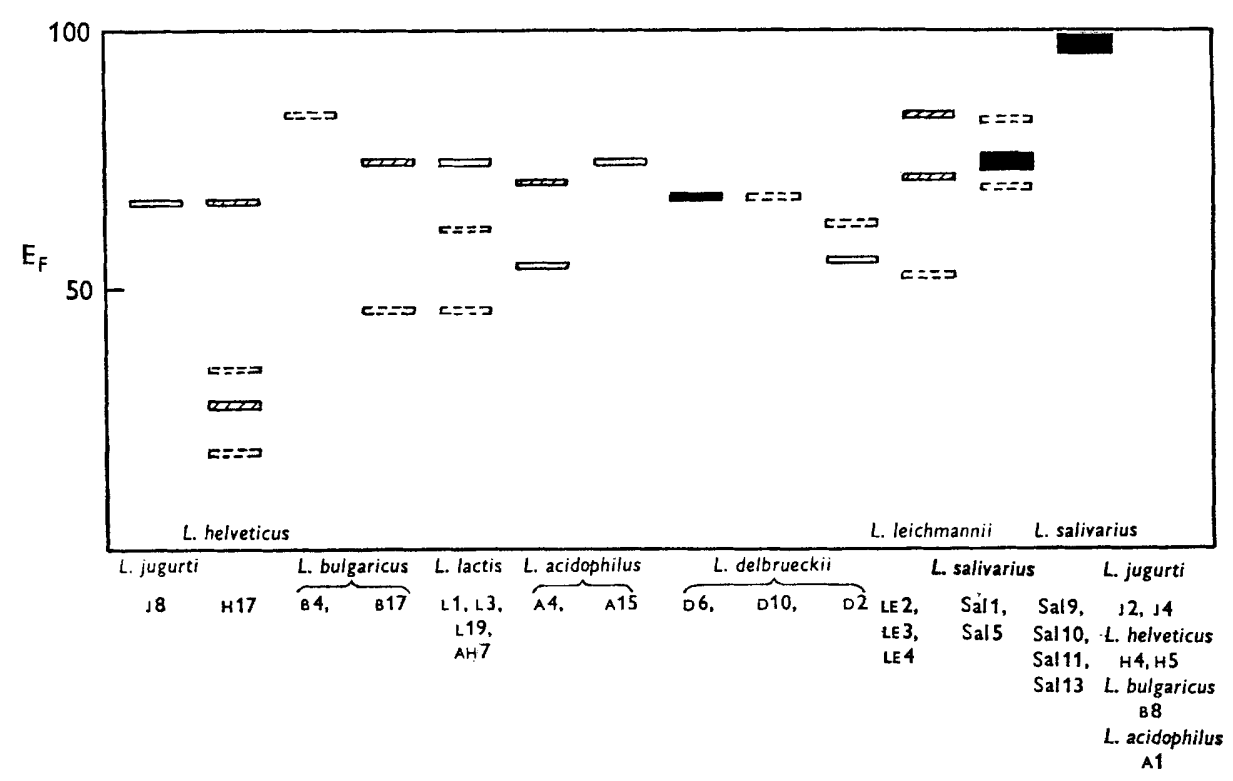

Fig. 2. Esterase patterns of thermobacteria.

\section{Esterase electrophoretic patterns of lactic acid bacteria}

Streptococci. Most of the lactic streptococci appeared to have a common esterase with a mobility of $E_{F} 62$ as shown diagrammatically in Fig. I, only in the extracts of three strains of Streptococcus cremoris was this common band either not detected or 
extremely weak. In general the species $S$. lactis appeared to possess a more complex esterase pattern than the species of S. cremoris. Streptococcus diacetilactis, which is physiologically nearest to $S$. lactis, had the same esterase pattern as this species. Two cultures of $S$. cremoris also had this pattern, but it was later found that these two cultures resembled $S$. lactis in ability to grow in glucose I \% Lemco broth containing $4 \% \mathrm{NaCl}$, and in fermenting maltose, but resembled S. cremoris in being unable to grow in milk at $37^{\circ}$ or above. Streptococcus cremoris 803 also seemed to be atypical, fermenting and clotting milk at $37^{\circ}$.

Lactobacillus: thermobacteria. Generally speaking, thermobacteria were weak in esterase activity under our experimental conditions. For six (H4, H5, J2, J4, B8, AI) of 28 strains belonging to the eight species tested, no esterases were detected (Fig. 2). Fifteen strains possessed one to four esterases which were generally very weak in activity. Lactobacillus delbrueckii $\mathrm{D} 6$ and six strains of $L$. salivarius showed a relatively strong band of esterase.

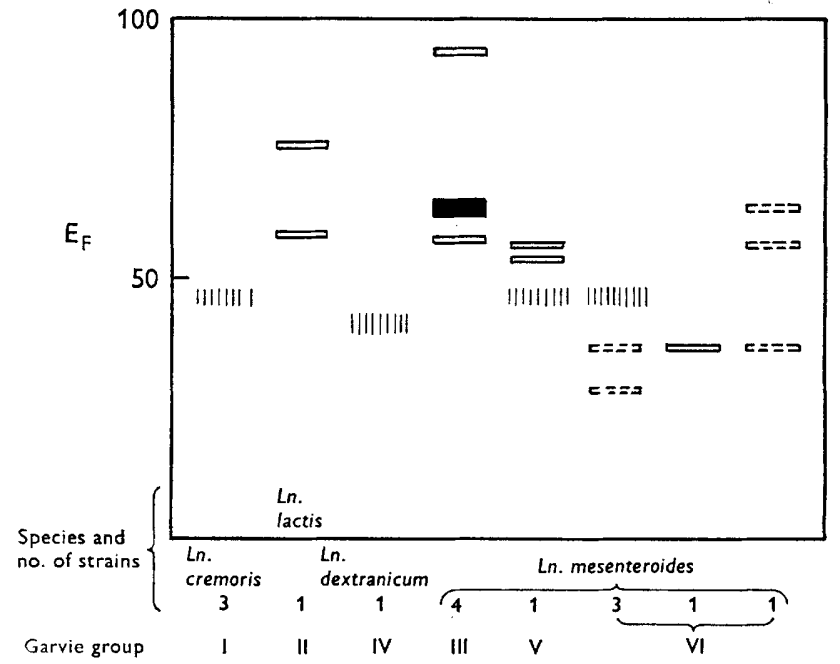

Fig. 3. Esterase patterns of leuconostocs.

All the strains of Lactobacillus lactis and L. leichmannii showed identical esterase patterns. No species-specific pattern was observed with the following six species: $L$. helveticus, $L$. jugurti, $L$. bulgaricus, $L$. acidophilus, $L$. delbrueckii, $L$. salivarius. Different incubation temperatures, i.e. $48 \mathrm{hr}$ at $25^{\circ}$ or $18 \mathrm{hr}$ at $37^{\circ}$ had no effect upon the esterase patterns of strains $L$. acidophilus AI 5 or $L$. bulgaricus $\mathbf{B} 4$.

Lactobacillus: streptobacteria. Sixteen of 17 strains of Lactobacillus casei showed the same esterase pattern which was characterised by a highly active band at $E_{F} 59$. No difference in the esterase patterns was observed among their three varieties, i.e. $L$. casei var. casei, var. rhamnosus and var. alactosus, nor between strains belonging to the different serological groups B and C (Sharpe \& Wheater, I957). Only one strain, CI2, had a distinctive esterase pattern and this strain possessed atypical physiological characteristics, not fermenting mannitol or melezitose. In addition to the abovementioned prominent band, one or two minor esterases were detected in the extracts of $L$. casei. For example, a very faint esterase band was usually observed at $\mathrm{E}_{\mathrm{F}} 70$. 
Species-specific patterns of $L$. plantarum were not consistently obtained; this was in contrast to the observations with $L$. casei.

There are many strains of streptobacteria which grow at low temperature and are homofermentative, but are neither Lactobacillus casei nor L. plantarum (Naylor \& Sharpe, 1958). Some of these unclassified strains were examined; strains AIOI, K44, D45 and v4 were found to be quite different from $L$. casei in esterase pattern. A few strains (e.g. A4I, V5) of this group showed no esterase activity under our conditions.

Generally speaking, the esterase activities of streptobacteria, especially $L$. case $i$, were higher than those of other lactobacilli with the exception of $L$. salivarius and of lactic streptococci.

Lactobacillus:betabacteria. No species-specific esterase pattern was obtained with the following organisms: Lactobacillus fermenti, L. buchneri, L. brevis, L. cellobiosus, $L$. pastorianus. The esterase activities were generally weak in these bacteria excepting $L$. cellobiosus. It is of interest that $L$. cellobiosus and $L$. salivarius, both of which were originally isolated from saliva, showed relatively high esterase activities.

Leuconostocs. All three test strains of Leuconostoc cremoris had an esterase at $\mathrm{E}_{\mathrm{F}} 46$; this was only weakly active and gave a diffuse zone (Fig. 3). Ten strains of Ln. mesenteroides gave two groups by the esterase analysis, four of them had a distinctive esterase pattern, the characteristic feature being a highly active esterase band at $E_{F} 64$; all these strains belong to Garvie's (I960) physiological group III. Six other strains of Ln. mesenteroides (Garvie's groups V and VI) were variable in esterase pattern, although the ill-defined esterase was generally detected at the same position as that for $L n$. cremoris. One strain each of $L n$. lactis and $L n$. dextranicum examined gave different esterase pattern from the other leuconostocs.

\section{Heat inactivation and inhibition of esterases}

The esterases of several lactic acid bacteria (Streptococcus cremoris HP, S. lactis $\mathrm{SC2}$, Lactobacillus casei C2, C6, C9, CIO) were inactivated at $60^{\circ}$ and $65^{\circ}$ for Io min. Esterases of $S$. cremoris ML3 and L. casei $\mathrm{C} 9$ were inhibited by $1 \mathrm{O}^{-4} \mathrm{M}$ difluorophosphate (DFP) but resistant to $10^{-4} \mathrm{M} c$-serine sulphate, $10^{-4} \mathrm{M}$ - $o$-iodosobenzoate, $10^{-4} \mathrm{M}-p$ hydroxy mercuribenzoate and $10^{-3} \mathrm{M}$-EDTA). These results suggest that these esterases are ali esterases (Augustinsson, 1958, I96I).

\section{Substrate specificities of esterases}

Most of the esterases of lactobacilli which were tested had greater activity against $\alpha$-naphthyl acetate, -butyrate and -caprylate in decreasing order. The esterases of some lactic streptococci hydrolysed $\alpha$-naphthyl acetate and -butyrate to the same extent. The esterase of Leuconostoc cremoris 543 showed greater activity against the butyrate ester than against the acetate. However, one should be careful when estimating the substrate specificity by gel electrophoresis, because it is more difficult for a substrate of low solubility, such as $\alpha$-naphthyl laurate, to diffuse to the enzyme in the polyacrylamide gel.

\section{Esterase in the culture supernatant fluid of Lactobacillus casei}

It was suggested by Stock, Uriel \& Grabar (I96I) that bacterial esterase and lipase Pollock, I962; Lawrence, Fryer \& Reiter, 1967) may be extracellular enzymes. To investigate this point Lactobacillus casei $\mathrm{c} 7$ was grownin MRS broth at $37^{\circ}$ for $33 \mathrm{hr}$ 
and the esterase activities of the samples of the fluid supernatant examined at intervals, by adding ammonium sulphate to samples to $2 / 3$ saturation and examining electrophoretically aqueous solutions of the precipitates in 0.1 M-phosphate buffer ( $\mathrm{pH} \mathrm{8.0)}$. Esterase activity was not detected in the supernatant fluid of the $L$. casei culture during incubation up to $33 \mathrm{hr}$. This result suggested that esterase liberation was negligible in a $L$. casei culture. The change of $\mathrm{pH}$ value of the culture during growth is presented in Table I. Such a $\mathrm{pH}$ change might have some influence upon the esterase present. When the cell-free extract was adjusted to $\mathrm{pH} 4 \cdot \mathrm{I}$ with $\mathrm{HCl}$ and incubated for $2 \mathrm{hr}$ at $37^{\circ}$ the greater part of the esterase was precipitated. This result does not mean that the isoelectric point of the esterase is $\mathrm{pH} 4 \cdot \mathrm{I}$; co-precipitation with other proteins in the cell-free extract, which contained about $20 \mathrm{mg}$. protein $/ \mathrm{ml}$., might be possible; also, the inactivation of enzymes liberated might not be unexpected at $\mathrm{pH} 3 \cdot 8$. To eliminate effects of low $\mathrm{pH}$ value, a culture of the same organism (L. casei $\mathrm{C} 7$ ) was held at $\mathrm{pH} 6.5$ by adding $\mathrm{NaOH}$. Esterase activity was then observed in the supernatant fluid after $17 \mathrm{hr}$ of incubation. The electrophoretic mobility of the liberated esterase was the same as that of the main esterase $\left(E_{F} 59\right)$ found after disrupting the bacteria. The proportion of the esterase activity which appeared in the supernatant fluid was estimated to be only i to $3 \%$ of the cell-bound enzyme.

Table I. Detection of esterase activity in the supernatant fluid of cultures of Lactobacillus casei strain $\mathrm{C7}$

\begin{tabular}{|c|c|c|c|c|c|}
\hline & & & of in & $(\mathrm{hr})$ & \\
\hline & & 8 & 17 & 26 & 33 \\
\hline $\begin{array}{l}\text { MRS broth, } \\
\text { pH unadjusted }\end{array}$ & $\begin{array}{l}\text { Esterase activity } \\
\text { pH }\end{array}$ & - & $\overline{4.05}$ & $\overline{3 \cdot 83}$ & $\overline{3} \cdot 75$ \\
\hline $\begin{array}{l}\text { MRS broth, } \\
\text { pH adjusted }\end{array}$ & $\begin{array}{l}\text { Esterase activity } \\
\text { pH }\end{array}$ & $\underset{6 \cdot 44}{ \pm}$ & $\stackrel{+}{6 \cdot 43}$ & $\stackrel{+}{6.53}$ & $\begin{array}{l}+* \\
6.50\end{array}$ \\
\hline
\end{tabular}

\section{Effect of trypsin on esterases of Lactobacillus casei}

Trypsin destroyed the esterases in the cell-free extract of Lactobacillus casei $\mathrm{C} 7$. However, when washed whole bacteria were suspended in $0.1 \mathrm{M}$-phosphate buffer ( $\mathrm{pH} 8 \cdot 0$ ) containing $2 \mathrm{mg}$. Armour crystallized trypsin $/ \mathrm{ml}$. and incubated at $37^{\circ}$ for $4 \mathrm{hr}$, no change occurred in the esterase activity. Accordingly the esterase in the whole cells seems to be protected from trypsin action.

\section{Esterase activity of whole bacteria}

The intensity of the colour reaction produced by a suspension of whole bacteria on paper impregnated with $\alpha$-naphthyl acetate and $0.02 \%$ of Fast blue salt correlated approximately with the esterase activities in cell-free extracts. About 60 strains of lactobacilli, streptococci and leuconostocs were compared by these two methods. Lactobacillus casei, L. salivarius and L. cellobiosus rapidly produced strong pink to red colours, while the weakly esterase positive or apparently negative strains such as H5, J2, B8, FI, A4I produced little or no colour. These results were further confirmed by using a $0.02 \%$ solution of indoxyl acetate as substrate (Barnett \& Seligman, I95I; Clarke \& Steel, 1966). Esterase-active organisms such as L. casei and L. salivarius 
produced in 2-3 $\mathrm{min}$. the deep blue colour of indican. Since control suspensions heated to $100^{\circ}$ for $2 \mathrm{~min}$. did not produce any colour, it was concluded that the reaction was caused by esterase activity.

\section{DISCUSSION}

Similarities in the electrophoretic patterns of soluble proteins such as those observed with the lactic streptococci may indicate similarity in the metabolism of the organisms, which is likely with these three species. The same applies to species of lactobacillus, where similar protein patterns were found within a species. Where there are marked differences of protein pattern within a species, as with Lactobacillus delbrueckii, perhaps further differentiation could be made by physiological and biochemical tests.

The esterase patterns confirm that esterase typing can help in the identification of some species of lactic acid bacteria. It seems possible to distinguish between Streptococcus cremoris and $S$. lactis by their characteristic esterase patterns. This is very similar to Lund's (1965) finding with $S$. faecalis and $S$. faecium. Lactobacillus casei strains showed a distinctive esterase pattern which may be helpful in identifying this species.

Most of the thermobacteria were weak in esterase activity under our conditions and few species-specific patterns were observed. Similarly, in the betabacteria the esterase activities were generally weak and the pattern variable, and would therefore be of little taxonomic value. Strains of Lactobacillus plantarum showed two to four bands, with great variation in pattern; Rogosa et al. (1953) has already suggested that $L$. plantarum as presently constituted, may not be homogenous.

In the study of Bacillus thuringiensis, Norris (1964) found a close correlation between esterase types and groups defined by the possession of $\mathrm{H}$ antigen. Although the Streptococcus cremoris strains used here could be subdivided into four groups based on their phage relationships and on agglutination with immune whey (Whitehead \& Bush, 1957; Reiter, Di Biase \& Newbould, 1964), there was no difference in esterase pattern among these subgroups. Leuconostoc mesenteroides could be divided by esterase pattern into two main groups which closely correlated to the grouping based on physiological tests proposed by Garvie (1960).

The present results indicate that many lactic acid bacteria possess active esterase. It is difficult to verify the 'true esterase', because non-enzymic proteins of milk and of serum (Downey \& Andrews, 1965) and some proteolytic enzymes also show esterase activity (Pickering \& Reiter, 1962). However, the esterase activities of lactic streptococci and streptobacteria were destroyed by conventional heat tests for enzymes. Inhibition experiment suggests that the activities of Streptococcus lactis ML3 and Lactobacillus casei $\mathrm{C} 9$ might be due to ali esterases.

The main esterase ( $\left.E_{F} 59\right)$ of Lactobacillus casei $\mathrm{C} 7$ was found to be a cell-bound enzyme. Liberation of esterase into the medium was negligible with growth in the ordinary culture medium unless the $\mathrm{pH}$ was maintained at $6 \cdot \mathrm{I} 5$ when a weak activity was detected in the supernatant fluid. However, the cell-bound esterase of $L$. case $i$ appeared to be stable, irrespective of the environmental low $\mathrm{pH}$ value, because it remained highly active in cells after prolonged incubation, such as 3 to 5 days at $37^{\circ}$.

The rapid decomposition of $\alpha$-naphthyl acetate by whole organisms of Lactobacillus case $i$ as indicated by the immediate development of colour on addition of $\alpha$-naphthyl 
acetate + staining solution suggests that the esterases of $L$. case $i$ might be situated on or near to the cell surface, because it is unlikely that these substances are incorporated rapidly into the organism. The location of the esterase may be just within the cell wall.

The authors wish to thank Mr B. A. Phillips for technical assistance.

\section{REFERENCES}

Augustinsson, K.-B. (1958). Electrophoretic separation and classification of blood plasma esterases. Nature, Lond. I8I, 1786.

Augustinsson, K.-B. (196I). Multiple forms of esterase in vertebrate blood plasma. Ann. N. Y. Acad. Sci. 94, 844 .

Barnett, R. J. \& Seligman, A. M. (1951). Histochemical demonstration of esterase by production of indigo. Science, N.Y. Ir4, 579.

CANN, D. C. \& Willox, M. E. (1965). Analysis of multimolecular enzymes as an aid to the identification of certain rapidly growing Mycobacteria, using starch gel electrophoresis. $J$. appl. Bact. 28, 165.

Clarke, P. H. \& Steel, K. J. (1966). Rapid and simple biochemical tests for bacterial identification. Identification Methods for Microbiologists, p. II I. New York and London: Academic Press.

DOWNEY, W. K. \& ANDREWs, P. (1965). Esterase activity of the non-enzymic proteins of milk and serum. Biochem. J. 96, 2 I C.

EFthymiou, C. \& ARne Hansen, P. (1962). An antigenic analysis of Lactobacillus acidophilus. J. infect. Dis. Iro, 258.

Evans, J. B. \& Niven, C. F. (I95I). Nutrition of the heterofermentative lactobacilli that cause greening of cured meat products. J. Bact. 62, 599.

GarviE, E. I. (1960). The genus Leuconostoc and its nomenclature. J. Dairy Res. 27, 283.

GOMORI, G. (1953). Human esterase. J. Lab. clin. Med. 42, 445.

ItZHAKI, R. F. \& Gill, D. M. (1964). A micro-biuret method for estimating proteins. Analyt. Biochem. 9, 4 IOI.

LaWrence, R. C., Fryer, T. F. \& ReITer, B. (1967). The production and characterization of lipases from a micrococcus and a pseudomonas. J. gen. Microbiol. 48, 401 .

LaWrence, S. H., Melnick, P. J. \& Weimer, H. E. (I960). A comparison of serum proteins and enzymes by starch gel electrophoresis. Proc. Soc. exp. Biol. Med. ro5, 572.

LuND, B. M. (1965). A comparison by the use of gel electrophoresis of soluble protein components and esterase enzymes of some group D streptococci. J. gen. Microbiol. 40, 4I3.

Man, J. C. DE, Rogosa, M. \& Sharpe, M. E. (1960). A medium for the cultivation of lactobacilli. J. appl. Bact. 23, 130.

Naylor, J. \& Sharpe, M. E. (1958). Lactobacilli in Cheddar cheese. II. Duplicate cheeses. J. Dairy Res. 25, $42 \mathrm{I}$.

NoRRIs, J. R. (1964). The classification of Bacillus thuringiensis. J. appl. Bact. 27, 439.

Pickering, A. \& ReIter, B. (1962). Rep. natn. Inst. Res. Dairy p. 70.

Pollock, M. R. (1962). Exoenzymes. In The Bacteria, vol. 4, p. III, New York and London: Academic Press.

Reiter, B., Di Biase, C. \& Newbould, F. H. S. (1964). A note on the serological typing of some strains of Streptococcus cremoris. J. Dairy Res. 3I, I25.

Reiter, B., Fryer, T. F., Sharpe, M. E. \& Lawrence, R. C. (1966). Studies on cheese flavour. J. appl. Bact. 29, 23I.

Reiter, B., Fryer, T. F., Pickering, A., Chapman, H. R., Lawrence, R. C. \& Sharpe, M. E. (1967). The effect of the microbial flora on the flavour and free fatty acid composition of Cheddar cheese. J. Dairy Res. 34, 257.

RoBinson, K. (1966). An examination of Corynebacterium spp. by gel electrophoresis. J. appl. Bact. 29, 179.

Rogosa, M., Wiseman, R. F., Mitchell, J. A., Disraely, M. N. \& Beaman, A. J. (1953). Species differentiation of oral lactobacilli from man. J. Bact. 65, 68I. 
Sharpe, M. E. \& WheATer, D. M. (1957). Lactobacillus helveticus. J. gen. Microbiol. 16, 676.

Stock, A. H., Uriel, J. \& GrabAR, P. (I961). Extracellular esterase of group A streptococci. Nature, Lond. 192, 434.

WhiteHEAd, H. R. \& Bush, E. J. (1957). Phage-organism relationships among strains of Streptococcus cremoris: the selection of strains as cheese starters. J. Dairy Res. 24, 381.

WRIGHT, T. R. F. \& KECK, K. (196I). Qualitative determination of esterase activities after starch gel electrophoresis. Analyt. Biochem. 2, 610. 